Dr. 2234

LA-8635-MS

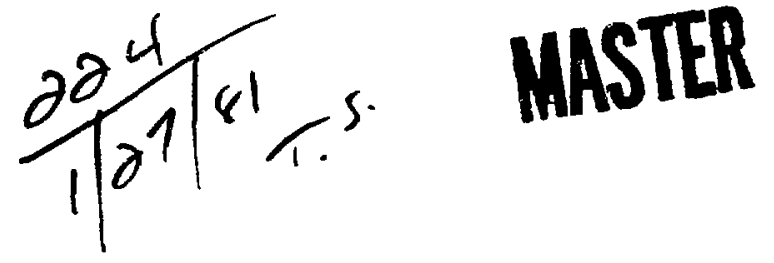

$$
i^{2}-1452
$$

Geohydrology of White Rock Canyon of the Rio Grande from Otowi to Frijoles Canyon 
UC-11

Issued: December 1980

\title{
Geohydrology of White Rock Canyon of the Rio Grande from Otowi to Frijoles Canyon
}

\author{
W. D. Purtymun \\ R. J. Peters \\ J. W. Owens
}




\title{
GEOHYDROLOGY OF WHITE ROCK CANYON OF THE RIO GRANDE FROM OTOWI TO FRIJOLES CANYON
}

\author{
by
}

W. D. Purtymun, R. J. Peters, and J. W. Owens

\begin{abstract}
Twenty-seven springs discharge from the Totavi Lentil and Tesuque Formation in White Rock Canyon. Water generally acquires its chemical characteristics from rock units that comprise the spring aquifer. Twentytwo of the springs are separated into three groups of similar aquifer-related chemical quality. The five remaining springs make up a fourth group with a chemical quality that differs due to localized conditions in the aquifer. Localized conditions may be related to recharge or discharge in or near basalt intrusion or through faults. Streams from Pajarito, Ancho, and Frijoles Canyons discharge into the Rio Grande in White Rock Canyon. The base flow in the streams is from springs. Sanitary effluent in Mortandad Canyon from the treatment plant at White Rock also reaches the Rio Grande.
\end{abstract}

\section{INTRODUCTION}

The Lus Alamos Scientific Laboratory (LASL) and the communities of Los Alamos and White Rock are located on the Pajarito Plateau wesi of the Rio Grande. The eastern edge of the plateau terminates along White Rock Canyon. This canyon is formed by downcutting of the Rio Grande (Fig. 1). The elevation of the Rio Grande is about $1680 \mathrm{~m}$ at Otowi decreasing to $1620 \mathrm{~m}$ at the confluence of Frijoles Canyon, about $18 \mathrm{~km}$ to the south. The western rim of the canyon is formed by the Pajarito Plateau, which rises as much as $340 \mathrm{~m}$ above the river. The eastern rim of the canyon is fornied by the uplands of La Mesita and Cerros dei Rio that rise above the river $200 \mathrm{~m}$ to $380 \mathrm{~m}$, respectively.

The Pajarito Plateau, west of the Rio Grande, is drained by Los Alamos, Sandia, Mortandad, Pa- jarito, Water, Ancho, Chaquihui, and Frijoles Canyons. The area east of the river is drained by Cañada Ancha and several smaller, unnamed canyons. With two exceptions, the canyons drop precipitiously into White Rock Canyon. The channels in Los Alamos Canyon and Cañada Ancha slope steeply to the river (Fig. 2).

Sanitary effluent from the treatment plant at White Rock forms a perennial flow in lower Mortandad Canyon that discharges into the Rio Granda. Base flow in streams in Pajarito and Ancho Canyons is from spring discharge from the Totavi Lentil. The springs provide perennial flow to the Rio Grande. The flow in lower Frijoles Canyon is intermittent, with discharge reaching the river when evapotranspiration rates are low. So' - water is discharged directly into the river from alluvial fans at the mouth of Los Alamos and Frijoles Canyons. 


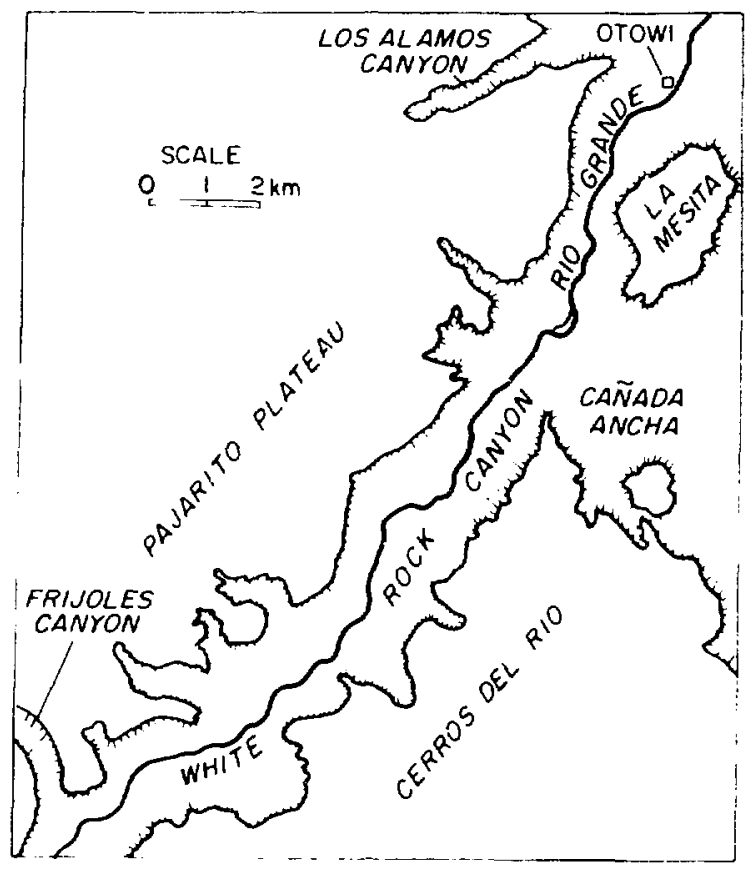

Fig. 1.

Topographic features adjacent to White Rock Canyon.

Twenty-seven springs and seeps are located in White Ruck Canyon from Otowi to Frijoles Canyon. Of these, seven are located on the east side of the Rio Grande. These springs discharge ground water from the upper surface of the main aquifer of the Los Alamos area (west of White Rock Canyon), which rises westward from the river through the Tesuque Formation. ${ }^{1.2}$ To the east the aquifer remains within the Tesuque Formation. East of the river, basalts intruded in and thro'ıgh the Tesuque Formation (at La Mesita and Cerros del Rio) form a partial barrier to ground water movement toward the river. ${ }^{3}$

In 1964, a study was made of the geohydrology of the White Rock Canyon." The chemical quality of 21 springs and 3 streams was described. These springs and stations on the streams are used as a part of the present water quality monitoring system. The springs and streams are sampled on an average of every two years for chemical and radiochemical analyses. The purpose of this paper is to update the 1964 report. This will provide a better basis for interpreting of water quality data for the annual report issued by LASL. "Environmental Surveillance at Los Alamos. "s-i

\section{GEOLOGY}

White Rock Canyon is located near the center of the Española Basin, which contains sediments and interbedded basalts. ${ }^{\text {T }}$ The canyon was formed by the downcutting of the Rio Grande through the basaltic rocks of Chino Mesa. The basaltic rocks form the rim and upper parts of the canyon walls (Figs. 3, 3A, 3B. $3 \mathrm{C}$ ). The Puye Formation underlies the basalts and is exposed in the canyon above the siltstones, sandstones, and interbedded basalts of the Tesuque Formation. The latter forms the lower part of the canyon walls and floor.

The Tesuque Formation and the Totavi Lentil (lower member of the Puye Formation) are described in detail as these units contain springs and seep areas. The description of the units is drawn largely from Griggs and are described from oldest to youngest. ${ }^{9}$

The Tesuque Formation is a sequence of lightcolored sediments laid down as coalescing alluvial fan and flood plain deposits in the Rio Grande depression. It is composed of moderately wellcemented beds of fine to coarse grained arkosic siltstone and sandstone and some conglomerate and clay lenses. The Tesuque Formation also contains some volcanic debris and interbedded basalts. North of the confluence of Water Canyon and the Rio Grande the sediments are mostly fine-grained. They are shown in Figs. 3A-3C as TS(FG). South of the confluence of Water Canyon and the river, the out crops of the Tesuque Formation contain interbedded basalt flows. The sediments above and below the basalts contain volcanic debris that is much coarser than the sandstone that is found in the Tesuque Formation to the north. These basalts and coarser sandstones are shown in Fig. 3C as TS(CG). The coarser sandstones and interbedded basalts are younger than the main body of the Tesuque Formation that is presen: from Otowi to Water Canyon.

The Puye Formation consists of two members. The lower member is a channel fill deposit named the Totavi Lentil. The upper member, the fanglomerate member, is composed of volcanic debris. 


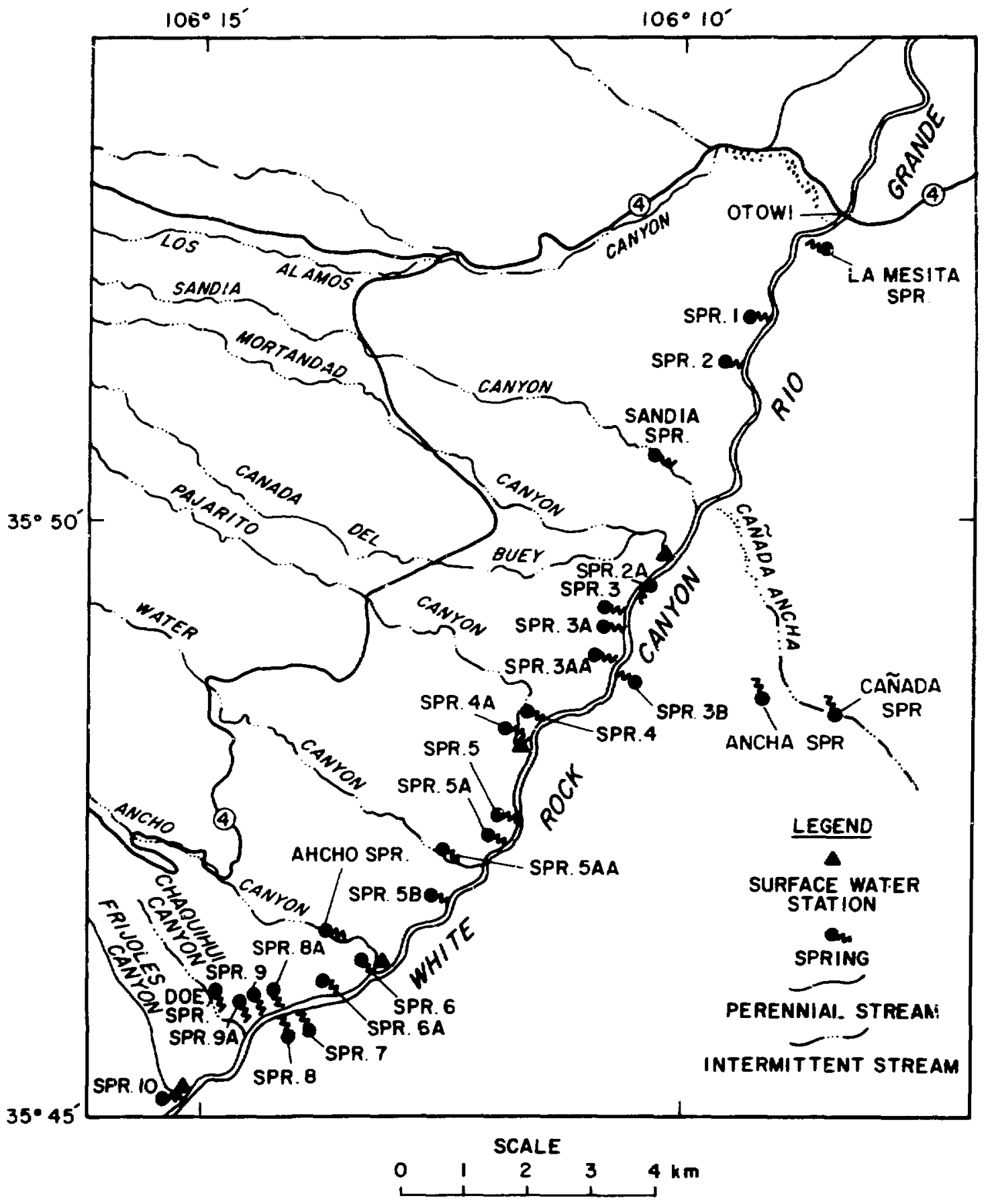

Fig. 2.

Generalized location of springs in White Rock Canyon. 
The Totavi Lentil overlies the Tesuque Formation along the Rio (rrande to a point below Ancho Canyon. Here it wedges nut between the underlying Tesuque Formation and the overlying basaltic rocks of (hino Mesa (Fig. 3("). The Lentil consists mainly of subrounded to well-rounded quartzite and quartz pebbles and boulders. Sorting is generaily poor. but well-sorted lenses of silt and sand are present. The thickness ranges from a few meters to about $15 \mathrm{~m}$. The Totavi Lentil is shown in Figs. $3 \mathrm{~A}-3 \mathrm{C}$ as QTp(TL).

The langlomerate member of the Puye Formation is a gray fanglomerate composed of rhyolite. latite. quariz latite, some basalt, and water laid pumice in a matrix of silt and sand. The fanglomerate overlies the Totavi Lentil south of Los Alamos Canyon and wedges out between the lentil and basaltic rocks of ('hino Mesa about $3 \mathrm{~km}$ south of Otowi. The fanglomerate does not outcrop along the eastern edge of White Rock Canyon. The fanglomerate member is shown as QTp in Fig. 3A. No springs or seeps issue from the fanglomerate member.

The basaltic rocks of Chino Mesa consist of numerous reddish-brown to black basalt flows. These are vesicular to dense and include interflow zones of clays silt. and basalt fragments. The basalts rest in the Tesuque Formation south of Ancho Canyon and on the Totavi Lentil and fanglomerate member north of Ancho Canyon. Along Los Alamos (anyon, younger basalt flows overlie the tanglomerate member. Basalt intrusion through the Tesuque Formation forms numerous plugs in La Mesita and Cerros del Rio. The basaltic rocks of Chino Mesa are shown in Figs. 3A-3C as QTb. The basalt ic rocks of Chino Mesa contain no springs or seeps.

Recent alluvium along the Rio Grande consists of silt to boulder-size debris of a variety of materiais. Vear Otowi the alluvium may be as much as $8 \mathrm{~m}$ thick: southward it forms a thin sheet overlying the Tesuque Formation. At the mouth of Los Alamos, Sandia. Mortandad, Pajarito, Ancho, and Frijoles Canyons large alluvial fans are deposited, causing the water to flow against the east cant on wall. The alluvium along the Rio Grande is not shown on Figs. $3 \mathrm{~A}-3 \mathrm{C}$ as it was not of consequence to this study.

\section{III, HYDROLOGY}

Water from springs generally acquires it - chemical characteristiss by solution of minerals in the rock units that compose the aquifer. Based on similar water quality and aquifer characterintics. the springs have been separated into four grouph. (irrup I -. springs that discharge from the Tot avi Lentil: Group II-springs that discharge trom the Tesuque Forma tion coarse-grained sedıments. (irutsp III springs that discharge from Tesuque Frormation tine-prained sediments, and Group IV-springs that dincharge near intrusion basalts or faults having :2 ingt it dit ferent chemical characteristic because "ff localized conditions of the aquifer. These (irup) IV springs discharge from the fine-grained Tesuyite Firmation along the east side of the canson. They are in the area of numerous basalt hows and intrusion that form La Mesila and Cerrus del Rirr.

High thow in the Rio Cirande ha- covered sime of the springs at times when samples une collected. st that in some years these data tre nu wing $A$ near complete set of data was collected in $19-2 x$ Thene chemical data are comsidered wh be representatise if the quality of water from the individual springs. The missing data were filled in from the mos resent years.

The chenical analyses were performed in determine the types of water and if chemical quation changes takes place with time. Vosamples were coll lected and analized for bacteria

In comparing data from individual springs and streams wer the sears, some slight varsation ip chemical quality is evident. The chemical variations are small and are due $t o$ seassonal influences such as rhanges in air temperaiure and the effects if evapotranspiration on spring discharge. The variations in water quality are within the range normally expected and are not considered significant.

Radiochemical analyses of spring and stream water are performed along with chemical analyses. Radiochemical analyses are for gress alpha, gross beta, ${ }^{137} \mathrm{Cs} .{ }^{23} \mathrm{Pu},{ }^{239} \mathrm{Pu}$. ${ }^{3} \mathrm{H}$. and iotal $\mathrm{C}$. The con. centrations of ${ }^{137} \mathrm{Cs}$. ${ }^{239} \mathrm{Pu}$. ${ }^{299} \mathrm{Pu}$, and ${ }^{3} \mathrm{H}$ have been below limits of detection in samples collected since 1967. During 1978 the limits of detection for ${ }^{13} \mathrm{C}$ s was $<120 \mathrm{pCi} / \ell$; ${ }^{29} \mathrm{P} \mathrm{M}$. and ${ }^{29} \mathrm{Pu}$ were $<0.02 \mathrm{pCi} / \boldsymbol{l}$ : 


\section{EXPLANATION}

OTB BASALTIC ROCK OF CMINO MESA

OTP PUYE FORMA TION (FANGLOMERATE MEMEER)

[OTPTIL] PUYE FORMATIONITOTANI LENTIL)

TICE] TESUOUE FORMATION (COANSE-GRAIREO SEDIMENTS

[TB(FG] TESUOUE FONMATION ( FIME - GRAIMEO SEDIMENTS)

a spaing

Pereninal stream

- - inteamittent sthegm

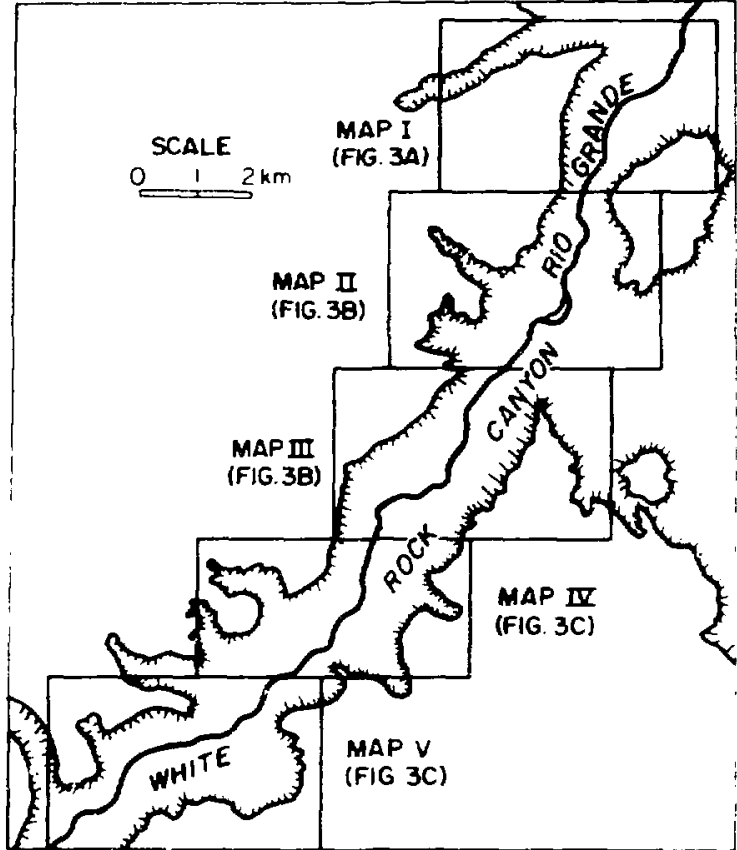

INDEX MAP

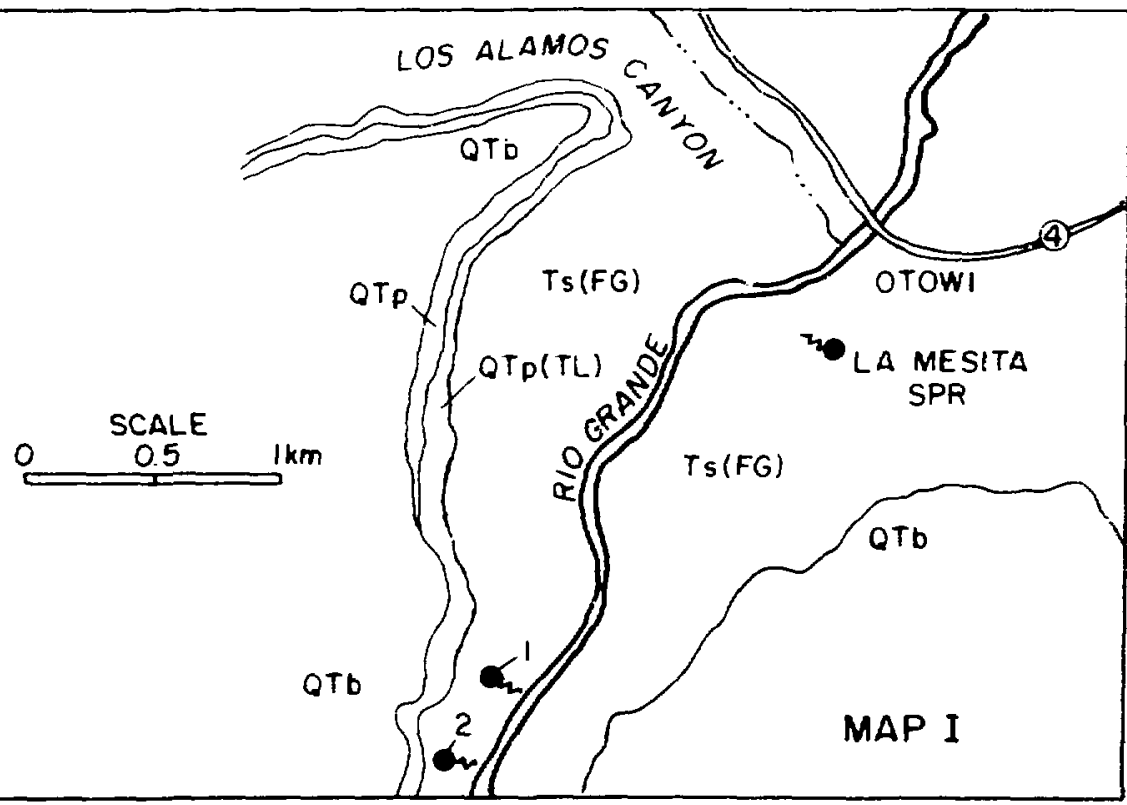

A. Map I.

Fig. 3.

Geologic map of White Rock Canyon. 

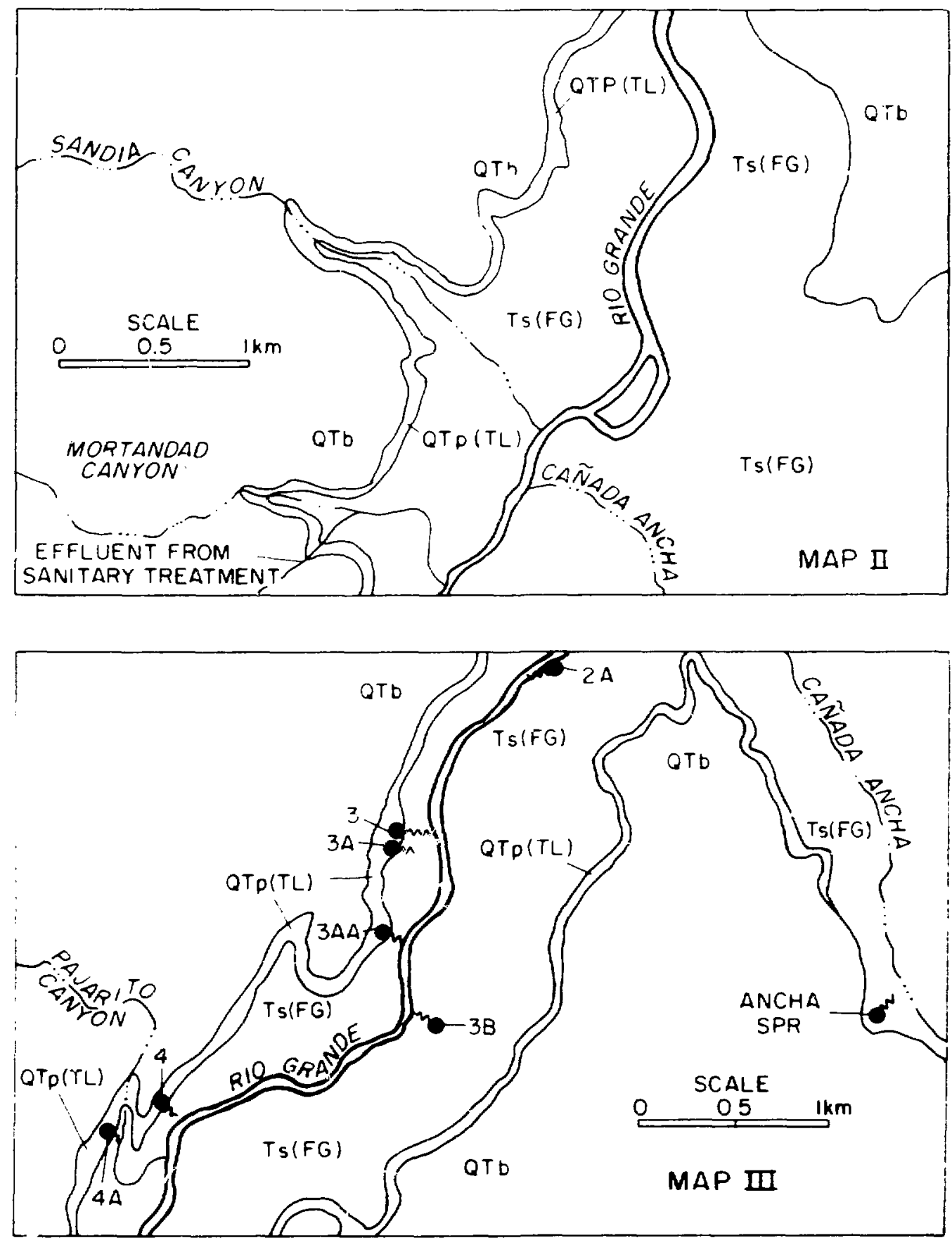

B. Maps II and III.

Fig. 3 (Cont) 

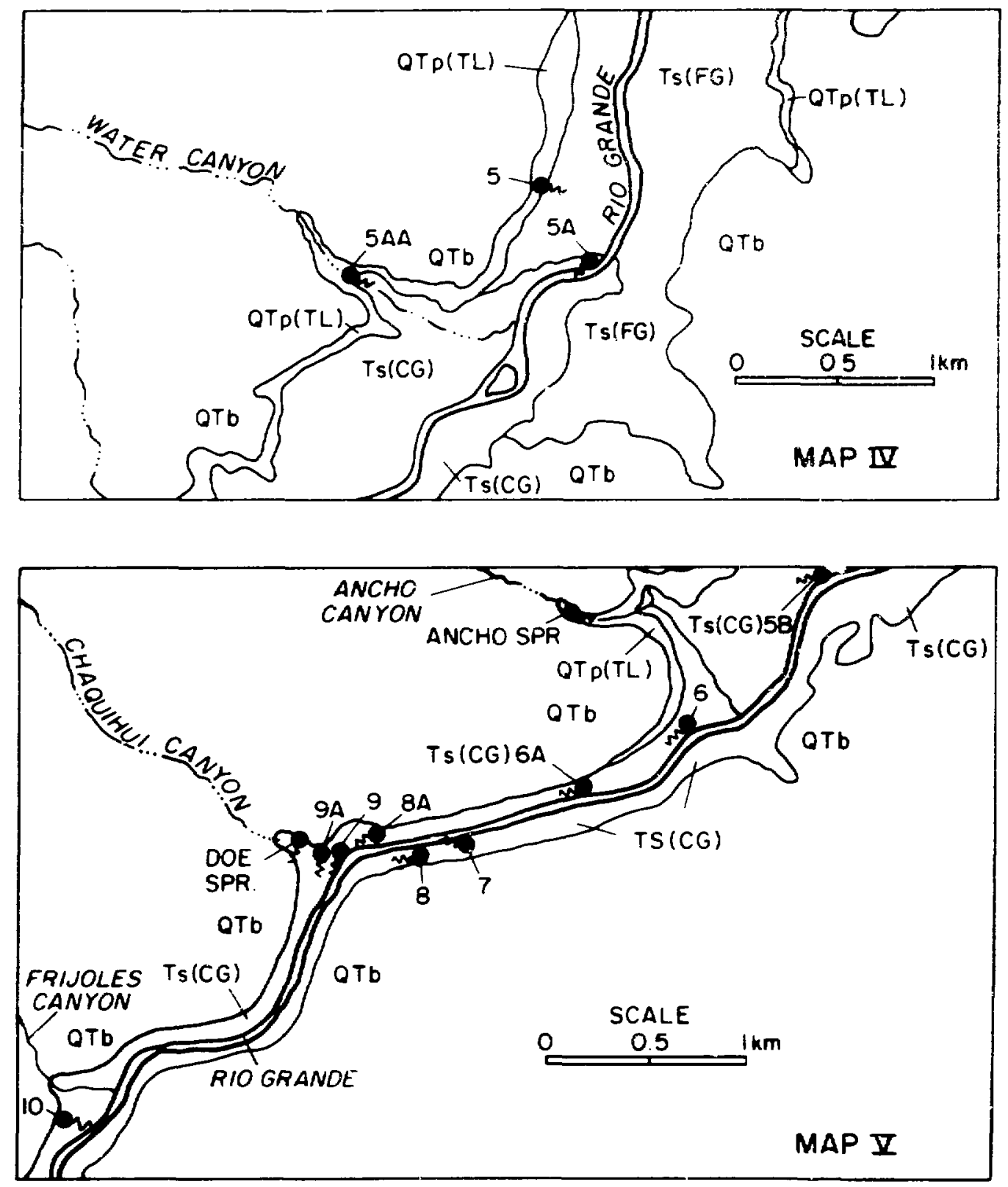

C. Maps IV and $V$

Fig. 3 (Cont) 
and ${ }^{3} \mathrm{H}$ was $<i 5(k) \mathrm{p}(\mathrm{i} / \mathrm{l}$." Thus, only the gross alpha. gross beta. and tutal $\mathrm{C}$ in water from the springs and streams are discussed. This radioactivity is natural, taken in the solution by the ground water mosing through the aquifers.

\section{A. Springs}

The (iroup I springs (Totavi Lentil) are all on the went side of the rwer. They range in elevation from 1.3. $\mathrm{m}$ in Sandia ('anyon to the north to $168.3 \mathrm{~m}$ near Pajaritu ('anyon and then increase in elevation to the wuth to $1737 \mathrm{~m}$ near Ancho Canye $n$ where the Tit avi Lentil wedges our between the coarse-grained Tesuque Furmation and basaltic rorks of Chino Mend IFigs. 3A-3C . Springs in this group form the hase fluw in Pajaritu and Ancho Canyon (Table I). 1)icharge from all bui (wo of the springs reaches the Rio (irande. The discharge in Sandia Canyon (Sandia springl and Water Canyon (Spring 5AA) is depleted hy infiltration into the alluvium and evapitranspiration before reaching the river.

Discharge trom the (irctup I springs is a calcium and bicarbonate water (Fig. 1). The average sulfate and chloride concentrations are about $4 \mathrm{mg} / l$. Total disoriled solids (Tllsi) range from 112 to $210 \mathrm{mg} / \ell$, wh h an average concentration of $16: 3 \mathrm{mg} / \boldsymbol{l}$ (Table 11.

The (iroup ll springs /Tesuque Formation, coarsegraned sedimentsl are located on both sides of White Rock (anyon. six of the springs (Springs 5A, 3B. ti. b.A. $T$ and 8 ire located at the edge of the (hannel (Fig. 2). These springs discharge about 30 $\ell$ - directly into the river. Springs in or near Chaquehui ('anyon ISprings 8A, 9, 9A, and Doe) are located 40 io $6010 \mathrm{~m}$ above the river. They provide water for large areas of vegetation. All discharge from Doe and Spring 9A is lost to infiltration or evaporation before reaching the river. Spring 10 discharges $<1) .1 \ell / \mathrm{s}$ from the edge of the alluvial fan at the mouth of Frijoles Canyon.

The discharge from the Group II springs is a sedium and bicarbonate water. The average sulfate and chloride concent rat $\mathrm{oms}$ are about $3 \mathrm{mg} / \mathrm{l}$. The TDS range from 154 to $262 \mathrm{mg} / \ell$. with an average concentration of $18.3 \mathrm{mg} / \mathrm{l}$.

The Group III springs (Tesuque Formation. finegrained sediments) are located on the west wall of the canyoun below Otowi (Fig 3A). The spring-form large seep areas that are covered with vegetation. There is nu discharge $t 0$ the river hecausf of the large losies to evapentanspiration.

Inischarge trum the (iroup III springs is also a sodium and bicarbonate water. Chemical concentrafion in weneral are higher thar in the (iroup I and (iroup II springs. Sulfate concentrations are about 11) $\mathrm{mg} / \ell$ while chlorides are low at $3 \mathrm{mg} / \ell$. The TDS ranges $1 \mathrm{rom} 194112.36 \mathrm{mg} / \ell$. With an average of 215 $\mathrm{m} m / \mathrm{l}$.

There are five springs in irmo 19. La Mesita. Ancha. 2A. : $\mathrm{B}$. and ('anada (Hg. : i ible Il): these springs are located on the sist side of the river. These springs discharge from the fine-yraned lesuque Formation where there are numerous basal flows and plugs as well as faults.

La Mesita sprirg is a seep area in and adjacent 10 a small channel that drains the steep western side of La Mesita (Fig. l1. La Mesita is formed by a series of intruded basalts. The seeps are in a part of the finegrained Tesuque Formation. At the source are the remains of a gallery set into the bank above the channel. The water 1 rom the gallery was probably used by the now aliandoned Denver and Rio (irande Railroad. La Mesita spring is about $20 \mathrm{~m}$ above the Rio (irande (Fig. 2). The spring discharges into the channel. The channel below the springs contains heavy growih of shrubs and trees, and only when evapotranspiration rates are low does water from the spring reach the Rio (irande. The discharge from La Mesita Sipring in a sodium and bicarbonate water. Sulfate is about $12 \mathrm{mg} / \ell$. chloride $6 \mathrm{mg} / \ell$, and TDS abuut $2 \times 6 i \mathrm{mg} / \mathrm{l}$.

Ancha Spring is located about $2.6 \mathrm{~km}$ east of the Rio Grande in a small caityon cut into the Cerros del Rio (Fig. 2). The small canyon is a tributary to Canada Ancha. Hater from the spring issues from near the contact of the basalt with underlying volcanic sediments. Water from the spring does not reach Canada Ancha. Discharge from the spring is a calcium and sulfate water. Sulfates are $212 \mathrm{mg} / \boldsymbol{l}$. chloride $5 \mathrm{mg} / \ell$. and TDS $508 \mathrm{mg} / \ell$, about twice the TDS concentrations found in other springs in White Rock ranyon.

Spring 2A is located on the east side of the river at about river level. The spring appears to discharge from fine-grained sediments of the Tesuque Formation; however, the chemical characteristics differ 
RECOKDS OF SHRINGS IN WHITE HOCK CANYON

\begin{tabular}{|c|c|c|c|c|c|}
\hline & $\begin{array}{c}\text { Elevation } \\
\text { (m) }\end{array}$ & Topographic Situation & $\begin{array}{l}\text { Temip } \\
\left({ }^{\circ} \mathrm{C}\right)\end{array}$ & $\begin{array}{c}\text { Diwehurse } \\
\text { ul } \\
\text { Hio Grande } \\
(l / s)\end{array}$ & Remarky \\
\hline \multicolumn{6}{|c|}{ Group I (Totavi Lentil) } \\
\hline Sandia Spring & $17: 17$ & Seep area in ard adjacent to channel & 卢 & 0 & Sandia Canyon \\
\hline Spring 3 & 1695 & Gravel terrace above river & 20 & 1 & \\
\hline Spring $3 A$ & 1695 & Gravel terrace above river & 22 & 3 & \\
\hline Sprink $3 A A$ & 1688 & Gravel terrace above river & 19 & $<1$ & \\
\hline Spriny 4 & 1683 & Gravel slope above river & 19 & 5.1 & \\
\hline Spring $4 A$ & 1683 & Grravel terrace abuve channel & 21 & 37 & Pajaritus Canyon \\
\hline Spring 5 & 1698 & Gravcl un steep slope alove river & 21 & 0.6 & \\
\hline Spring $5 A A$ & 1756 & Seep in channel fornis pools & 18 & 0 & Water Canyon \\
\hline Ancho Spring & 1737 & Gravels underlying basale in channel & 22 & 4.3 & Ancho Canyon \\
\hline \multicolumn{6}{|c|}{ Group II (Teauque Pm. Coarwe Grained) } \\
\hline Spring $5 A$ & 1645 & Fractures in basalt al edge of river & 21 & 1.7 & \\
\hline Sprink $5 B$ & 1646 & Stsep slope at edge of river & 16 & 0.6 & \\
\hline Spring 6 & 1640 & Fracturey in basalt at edge of river & $2: 3$ & 1.6 & \\
\hline Spring $6 A$ & 1638 & Practures in basnlt at river level & 22 & 9.5 & \\
\hline Spring 7 & $16: 77$ & Slope at edge of river & 21 & 11 & \\
\hline Spring 8 & $16: 17$ & Slope al edge of river & 22 & 4.4 & \\
\hline Spring BA & 1682 & Seep in channel on canyon wall & 22 & 1.6 & \\
\hline Spring 9 & 1679 & I arge seep area above river & 20 & 11.5 & \\
\hline Sprink $9 A$ & 1644 & Seep area on canyon wall & 19 & 0 & Chaquihui Canyun \\
\hline Doe Spring & 1707 & Seep area in channe! and canyon wall & 21 & o & Chuquihui Canyon \\
\hline Spring 10 & 1634 & Edge of alluvial fan abuve river & 19 & $<1$ & frijolex Canjou \\
\hline \multicolumn{6}{|c|}{ Grosp III (Tesuque Fe. Fla Gralned) } \\
\hline Spring 1 & 1711 & Seep ares on slope ubove river & 18 & 0 & \\
\hline Sprins 2 & 1707 & Soep area on alupe abuve river & 17 & 0 & \\
\hline \multicolumn{6}{|c|}{ 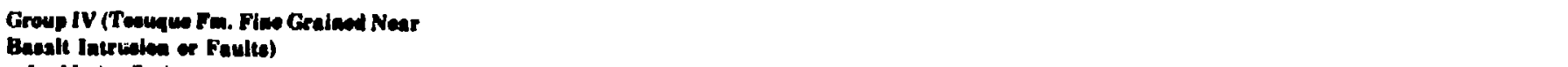 } \\
\hline La Mevita Sprin & 1700 & Seep area in und abuve channel & 17 & $<1$ & Hemains of gallery above channol \\
\hline Ancha Spting & 1760 & Seep ares in channel, volcanic wediments & 21 & 0 & \\
\hline Spring $2 A$ & 1675 & Gravel along edge of river & 22 & $<1$ & \\
\hline Spring 38 & 1676 & Terrace on slope above river & 20 & 2 & \\
\hline Carade Spring & 1682 & Seep area in Canada Ancha & 19 & ) & \\
\hline
\end{tabular}


$\mathrm{mg} / \mathrm{l}$

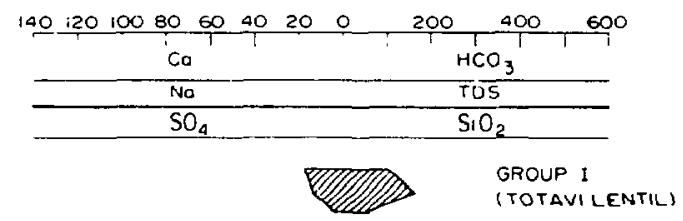

GROUP II

(TESUQUE Fm CG)

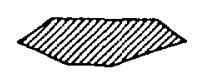

GROUP W

(TESUQUE Fm FG)

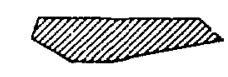

GROUP DT (LA MESITA SPR)
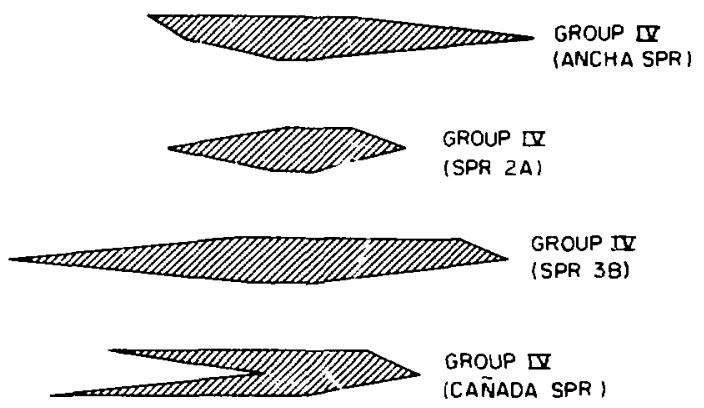

Fig. 4.

Graphic comparison of chemical characteristics of water from springs.

from other springs in the canyon. The discharge to the river is estimated at less than $0.1 \ell$ /s. The discharge from spring $2 \mathrm{~A}$ is a sodium and bicarbonate water. The sulfates are about $7 \mathrm{mg} / \ell$, chlorides 2 $\mathrm{mg} / \ell$, and TDS $270 \mathrm{mg} / \ell$.

Spring $3 \mathrm{~B}$ is located east and about $30 \mathrm{~m}$ above the Rio Grande. The main discharge is from the top of a low mound on a moderate slope. The mound is composed of a blue clay containing gravels of rounded quartz and quartzite. The surface of the area is covered with black vescular basalt and red scoria. Numerous seeps supporting a thick cover of salt grass occur in the area. About $2 \ell / \mathrm{s}$ of discharge from the spring and seeps reach the river. Tisisharge from spring $3 \mathrm{~B}$ is also a sodium and bicarbonate water. Sulfates are $16 \mathrm{mg} / \ell$, chlorides $4 \mathrm{mg} / l$, and TDS are elevated at $500 \mathrm{mg} / \ell$.
Canada Spring is located east of the Ric Grande in the channel of Canada Ancha. It is a seep area in fine-grained sediments of the Tesuque Formation adjacent to a basalt plug. The discharge from the spring is a calcium and bicarbonate water. Sulfates are $106 \mathrm{mg} / \ell$. chlorides $3 \mathrm{mg} / \ell$, and TDS $298 \mathrm{mg} / \ell$ ('Table II).

Gross alpha, gross beta and total $\mathrm{U}$ in water from the springs and streams are due to natural radioactivity taken into solution from the aquifer (Table III). Concentrations of gross alpha and gross beta were similar in Group I, II, and III springs. The concentration of total $\mathrm{U}$ in Groups I and II was slightly higher than Group III springs.

Gross alpha, gross beta, and total $\mathrm{U}$ were generally higher in Group IV springs (La Mesita, Ancha, 2A, $3 \mathrm{~B}$, and Canada) than in water from Groups 1 , II, or III. Gross alpha, gross beta, and total U concentration in water from Spring $3 \mathrm{~B}$ has been consistently higher than water from any of the other springs in the canyon. The radioactivity is natural occurring, leached from the rock units of the aquifer. Water from the Group IV springs is also highiy mineralized.

The chemical quality of water from the four groups of springs is quite good. The maximum concentrations of $\mathrm{SO}_{4}, \mathrm{C} \ell, \mathrm{F}, \mathrm{NO}_{3}$, and TDS are well below drinking water standards (Table IV). The concentrations of gross alpha, and total $U$ in water from the Groups I, II, and III springs were below drinking water standards. ${ }^{10}$ Measurements of gross alpha in water from the Group IV springs (La Mesita, Ancha, $2 \mathrm{~A}$. and $3 \mathrm{~B}$ ) range from 5.5 to $13 \mathrm{pCi} / \ell$ or above the standard of $5 \mathrm{pCi} / \ell$. This may be due to presence of ${ }^{226} \mathrm{Ra}$. Additional analyses are necessary to validate the vater for domestic use. Total U in the Group IV is well below drinking water standards. ${ }^{11}$

\section{B. Streams}

Streams from Mortandad, Pajarito, Ancho, and Frijoles Canyons enter the Rio Grande between Otowi and Frijoles Canyons. Base flow in Mortandad is sanitary ei:luent from the treatment plant at White Rock. Base flow in Pajarito and Ancho Canyons is from springs discharging from the Totavi Lentil near the Rio Grande. Base flow in Frijoles Canyon is from a series of headwater springs located about $13 \mathrm{~km}$ west of the Rio Grande on the flanks of 
TABLE ॥

WATE:H QUALITY OF STPKINGS AND STHEAM IN WHITE ROCK CANYON

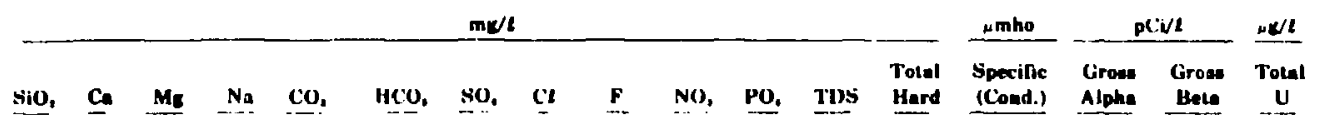

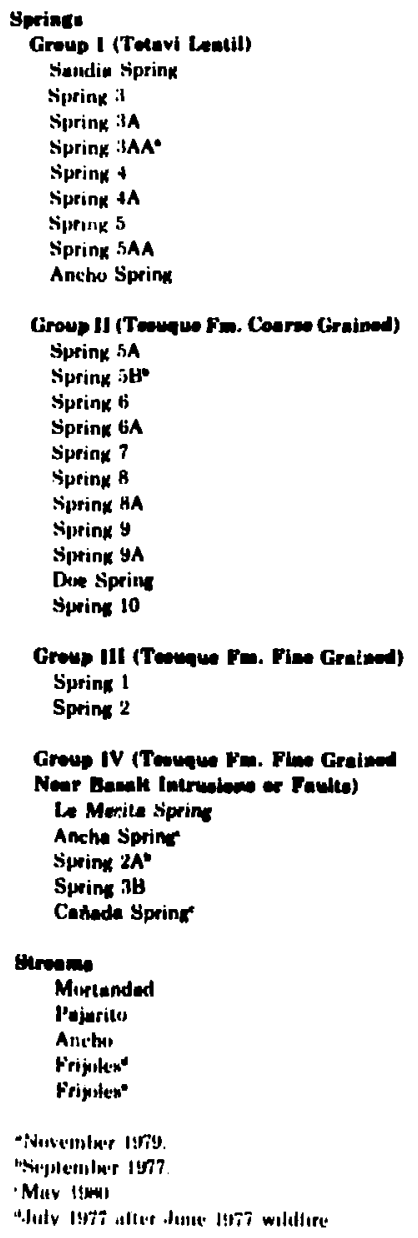

\begin{tabular}{|c|c|c|c|c|c|c|c|c|c|c|}
\hline 3 & 1 & II.A & $<2$ & $<2$ & 210 & I1L5 & 2901 & $<115$ & +.2 & $1 \mathrm{HA}$ \\
\hline 4 & 1 & 184 & 2 & $<2$ & 170 & +4 & 150 & $11 i$ & +5 & 10.5 \\
\hline 4 & 2 & 114 & 2 & $<2$ & litis & SH & 170 & 2.0 & 2.5 & u.g \\
\hline 4 & $: 1$ & 0.4 & $<2$ & $<2$ & 14:2 & H & $2+0$ & 2.0 & t. & Iy \\
\hline 9 & hi & 11.2 & $<2$ & $<2$ & $15: 2$ & 75 & 211 & 21 & 37 & $1 . \mathrm{A}$ \\
\hline 5 & 5 & 0.5 & $<2$ & $<2$ & 180 & 77 & :2010 & 1.7 & 1.1 & 7 \\
\hline 5 & 4 & 114 & $<2$ & $<2$ & 112 & 72 & 210 & 0.7 & 17 & (1). 1 \\
\hline 3 & 4 & 0.5 & $<2$ & $<2$ & IENH & N: & 210 & 2.4 & 3.t & 0.1 \\
\hline 2 & 2 & 0.3 & $<2$ & $<2$ & 194 & 57 & $1: 30$ & $<0.5$ & 2.4 & (1) 1 \\
\hline
\end{tabular}

\begin{tabular}{|c|c|c|c|c|}
\hline 54 & 16 & 2.5 & 19 & 0 \\
\hline & 18 & 3.0 & 12 & 0 \\
\hline : & 8 & 3.1 & 10 & 0 \\
\hline :35 & 7 & 2.2 & 10 & 0 \\
\hline 35 & 8 & 2.3 & is & a \\
\hline Gis & 13 & 3.8 & 22 & 0 \\
\hline 72 & 6 & 1.7 & 11 & 0 \\
\hline 70 & 8 & 2.5 & 11 & 0 \\
\hline 70) & 7 & 2.2 & II & 0 \\
\hline 66 & 8 & 2.5 & II & 0 \\
\hline 62 & 8 & 2.5 & 11 & 0 \\
\hline
\end{tabular}

\begin{tabular}{|c|c|c|c|c|c|}
\hline 102 & 7 & $t$ & (1) & $<2$ & $<2$ \\
\hline (I) & . & ; & 11.2 & $<2$ & $\ldots$ \\
\hline M5 & 2 & 2 & 11.3 & $<2$ & $<2$ \\
\hline (ii) & 2 & 2 & "1) 2 & $<2$ & $<2$ \\
\hline 78 & 3 & 2 & 0.2 & $<2$ & $<2$ \\
\hline $1 \% 2$ & 7 & : & 11.3 & $<2$ & $<2$ \\
\hline bitis & 2 & $\because$ & 11.3 & $<2$ & $<2$ \\
\hline $17: 1$ & 2 & 2 & 134 & $<2$ & $<2$ \\
\hline 75 & 2 & 2 & 10.5 & $<2$ & $<2$ \\
\hline 73 & 2 & 2 & 115 & $<2$ & $<2$ \\
\hline 78 & 2 & 2 & 0.5 & $<2$ & $<2$ \\
\hline
\end{tabular}

\begin{tabular}{|c|c|c|c|c|c|}
\hline 2001 & 6N & $2: 31)$ & 0.5 & $: 1.6$ & 1.3 \\
\hline 262 & 돘 & 190 & $<0.5$ & 3.4 & 0.1 \\
\hline 160 & 58 & $1+0$ & $<0.5$ & 2.3 & 0.6 \\
\hline IS4 & 41 & 120 & $<0.5$ & 2.5 & $<0.1$ \\
\hline 162 & .50 & 150 & 1.5 & 34 & 0.2 \\
\hline 250 & $\mathbf{H 0}$ & $2 * 0$ & 2.1 & I.5 & 1.8 \\
\hline 160 & : 15 & 120 & $<115$ & 2.0 & $<0.1$ \\
\hline 170 & 6) & 130 & $<0.5$ & 2.2 & (1). 1 \\
\hline $\mid(x)$ & 45 & 130 & 1.7 & 0.2 & 04 \\
\hline 154 & 12 & 140 & $<0.5$ & 3.6 & $<0.1$ \\
\hline 160 & 70 & 140 & 0.7 & 1.3 & $<0.1$ \\
\hline
\end{tabular}

$\begin{array}{lllll}32 & 24 & 1.9 & 32 & 0 \\ 30 & 13 & 0.5 & 47 & 0\end{array}$

\footnotetext{
170 $1: 3$
}

$\begin{array}{llll}117 & <2 & <2 & 194 \\ 10 & <2 & <2 & 236\end{array}$

$\begin{array}{rrrrr}19 & 27 & 0.6 & 29 & 0 \\ 16 & 66 & 2.3 & 49 & 0 \\ 42 & 3 & 0.1 & 56 & 0 \\ 44 & 21 & 1.8 & 126 & 0 \\ 28 & 01 & 1.6 & 10 & 0\end{array}$

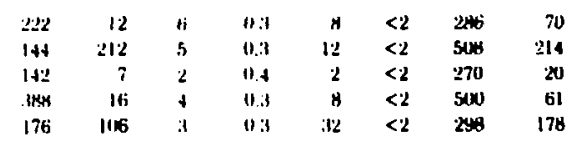

$\begin{array}{cccc}270 & 6.3 & 7.0 & 14 \\ 170 & 8 & 11 & 14 \\ 270 & 5.5 & 4.5 & 8.0 \\ 620 & 11 . & 11 & 20 \\ 350 & 3.2 & 5.1 & 1.7\end{array}$

$\begin{array}{rrrrr}84 & 16 & 7.6 & 75 & 5 \\ 64 & 15 & 1.3 & 13 & 0 \\ 64 & 9 & 2.8 & 10 & 0 \\ 7 . & 32 & 4.0 & 1.1 & 0 \\ 52 & 12 & 11.2 & 111 & 11\end{array}$

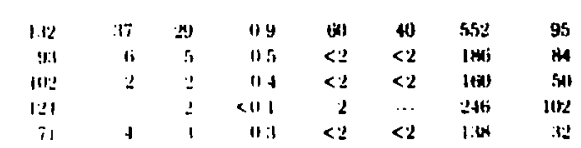

$\begin{array}{rrrr}600 & <1.5 & 18 & 11.5 \\ 200 & 2.5 & 4.3 & 11.4 \\ 140 & <0.5 & 2.2 & <1.1 \\ 260 & 1.7 & 10 & 11.9 \\ 110) & <1.5 & 11 & <11.4\end{array}$


TABLE III

GROSS ALPHA, GROSS BETA, AND TOTAL URANIUM IN WATER FROM SPAINGS (Analyses in $\mathrm{pCi} / \ell$ except az noted)

\begin{tabular}{|c|c|c|c|c|}
\hline & & & Gross Alphn & \\
\hline & Min & Mex & $\overline{\mathbf{x}}$ & $\leq$ \\
\hline Group I & $<0.5$ & 2.4 & 1.4 & 0.9 \\
\hline Group II & $<0.5$ & 2.1 & 0.9 & 0.6 \\
\hline Group III & 0.9 & 1.0 & 1.0 & 0.1 \\
\hline Gmup IV: & & & & \\
\hline La Mesita & ... & 6.3 & $\ldots$ & $\ldots$ \\
\hline Ancha & ... & 8.0 & ... & ... \\
\hline Spring 2A & $\ldots$ & 5.5 & $\cdots$ & $\cdots$ \\
\hline Spring 3B & $\cdots$ & 13.0 & $\cdots$ & $\cdots$ \\
\hline Cañada & $\cdots$ & 3.2 & $\cdots$ & $\cdots$ \\
\hline & & & Gross Beta & \\
\hline & Min & $\underline{\text { Max }}$ & $\overline{\mathbf{I}}$ & \pm \\
\hline Group I & 1.1 & 5.4 & 3.4 & 1.5 \\
\hline Group II & 0.2 & 3.6 & 2.6 & 1.1 \\
\hline Group IIJ & 1.8 & 3.9 & 2.8 & 1.5 \\
\hline Group IV & & & & \\
\hline La Mesita & $\cdots$ & 7.0 & ... & ... \\
\hline Ancha & $\ldots$ & 11.0 & $\cdots$ & $\ldots$ \\
\hline Spring 2A & $\cdots$ & 4.5 & $\cdots$ & $\cdots$ \\
\hline Spring 3B & $\cdots$ & 11.0 & $\cdots$ & $\cdots$ \\
\hline Cañada & $\cdots$ & 5.1 & $\cdots$ & $\cdots$ \\
\hline & & & Total Un & \\
\hline & $\underline{\text { Min }}$ & $\underline{\operatorname{Max}}$ & $\bar{x}$ & 8 \\
\hline Group I & $<0.01$ & 1.9 & 0.6 & 0.6 \\
\hline Group II & $<0.1$ & 1.3 & 0.5 & 0.6 \\
\hline Group III & 2.2 & 2.3 & 2.2 & 0.1 \\
\hline Group IV & & & & \\
\hline La Mesita & ... & 14.0 & $\cdots$ & $\ldots$ \\
\hline Ancha & $\cdots$ & 14.0 & $-\cdot$ & $--\cdot$ \\
\hline Spring ?A & $\ldots$ & 8.0 & $\cdots$ & $\cdots$ \\
\hline Spring $3 B$ & $\ldots$ & 20.0 & $\cdots$ & -.. \\
\hline Cañada & $\cdots$ & 3.7 & $\ldots$ & $\cdots$ \\
\hline
\end{tabular}

the mountains. A comparison of the chemical characteristics of the four streams is shown in Fig. 5 and detailed analyses are presented in Table II. Stream samples are collected above the confluence with the Rio Grande.

The chemical quality of water in Mortandad Canyon is typical of treated sanitary effluent. Sodium is $75 \mathrm{mg} / \ell$, sulfate $37 \mathrm{mg} / l$, chlorides $29 \mathrm{mg} / \ell$, nitrates $60 \mathrm{mg} / l$, and TDS at $552 \mathrm{mg} / l$ (Table II). Most chemical constituents are higher than found in natural waters of the region.

Base flow in Pajarito Canyon is principally a calcium and bicarbonate-type water similar to that discharging from springs in the Totavi Lentil (Table II). Sulfates are about $6 \mathrm{mg} / \ell$, chlorides about 5 $\mathrm{mg} / \boldsymbol{l}$, and TDS about $186 \mathrm{mg} / \boldsymbol{l}$. The base flow in Ancho Canyon is a sodium and bicarbonate water. Though the main base flow is from springs in the Totavi Lentil, water from the coarse-grained sediments of the Tesuque Formation is adderi $\approx$ the flow. Consequently, the flow increases downgradient in the canyon. Sulfates and chlorides are about 2 $\mathrm{mg} / \ell$ and TDS $160 \mathrm{mg} / \ell$ (Table II).

A wildfire in June 1977 burned about $26 \mathrm{~km}^{2}$ of the drainage area in upper Frijoles Canyon. Investigation of the chemical quality of the stream at Bandelier National Monument Headquarters (about $4 \mathrm{~km}$ from the river) indicates slight post-fire in creases in calcium, bicarbonate, chloride, fluoride, and TDS in the base flow when compared to data collected from 1957 through March $1977 . .^{12}$ Analyses of the water from Frijoles stream at the Rio Grande in July 1977 indicated slightly higher concentrations of calcuim, bicarbonate, and TDS when compared to analyses of water collected in November 1979 (Table II). Principal ions in 1979 were calcium and bicarbonate with sulfate concentrations of 4 $\mathrm{mg} / \boldsymbol{l}$, chlorides $3 \mathrm{mg} / \boldsymbol{l}$. and TDS $138 \mathrm{mg} / \boldsymbol{l}$ (Table II). With continued flushing of the burn area by storm runoff and recovery of the vegetative cover, the quality of water in the stream will return to normal within 3 to $5 \mathrm{yr}$.

Gross alpha, gross beta, and total U concentrations are normal in water from the stream near the Rio Grande, with the exception of gross beta (18 $\mathrm{pCi} / \ell$ ) from Mortandad Canyon (Table V). Treated sanitary effluents almost always contain higher gross beta activity than natural waters due to higher concentrations of potassium. ${ }^{7}$

The chemical quality of water from the streams is generally quite good. The concentrations of $\mathrm{SO}_{4}, \mathrm{C} \ell$, $\mathrm{F}, \mathrm{NO}_{3}$, and TDS meet the drinking water standards with the exception of $\mathrm{NO}_{3}$ in sanitary effluents in Mortandad Canyon. The NO, of the effluents is about $20 \mathrm{mg} / \boldsymbol{l}$ greater than permitted for domestic use (Table IV). The gross alpha and total $U$ are below standards or criteria. ${ }^{10}$

The release of sanitary effluent in Mortandad Canyon has little or no effect on the chemical quality of water in the Rio Grande because of the dilution factor. The discharge of effluent at the Rio Grande is $<0.03 \mathrm{~m}^{3} / \mathrm{s}$ compared to the mean discharge of the Rio Grande of about $30 \mathrm{~m}^{3 /} / \mathrm{s}^{13}$ 
TABLE IV

COMPARISON OF MAXIMUM CONCENTRATIONS OF SELECT CHEMICAL AND RADIONUCLIDE CONCENTRATIONS WITH DRINKING WATER STANDARDS

\begin{tabular}{|c|c|c|c|c|c|c|c|}
\hline & \multicolumn{5}{|c|}{$\mathrm{mg} / \mathrm{l}$} & \multirow{2}{*}{$\begin{array}{l}\text { Gross } \\
\text { Alpha }\end{array}$} & \multirow{2}{*}{$\begin{array}{c}\text { Total } \\
U^{c}\end{array}$} \\
\hline & SO. & $\mathrm{C} \ell$ & $\mathbf{F}$ & $\mathrm{NO}_{3}$ & TDS & & \\
\hline Standards ${ }^{\mathrm{A}}$ & 600 & 250 & 1.6 & 45 & 1000 & 5 & 1800 \\
\hline \multicolumn{8}{|l|}{ Springs } \\
\hline Group I & 9 & 6 & 0.8 & 2 & 210 & 2.6 & 1.9 \\
\hline Group II & 7 & 5 & 0.5 & $<2$ & 262 & 2.1 & 1.3 \\
\hline Group III & 13 & 3 & 1.0 & $<2$ & 236 & 1.0 & 2.3 \\
\hline Group IV & 212 & 6 & 0.4 & 32 & 508 & 13 & 20 \\
\hline \multicolumn{8}{|l|}{ Streams } \\
\hline Natural ${ }^{\mathrm{d}}$ & 6 & 5 & 0.5 & 2 & 246 & 2.5 & 0.9 \\
\hline Effluent" & 37 & 29 & 0.9 & 60 & 552 & $<0.5$ & 0.5 \\
\hline
\end{tabular}

"USEPA National Interim Primary Drinking Water Standards and NMEID Water Supply Regulations. ${ }^{10.11}$

${ }^{\mathrm{p}} \mathrm{pCi} / \boldsymbol{l}$.

' $\mu \mathrm{g} / \boldsymbol{l}$.

'Pajarito, Ancho, and Frijoles stream.

"Mortandad stream, sanitary effluent.

$\mathrm{mg} / \boldsymbol{l}$

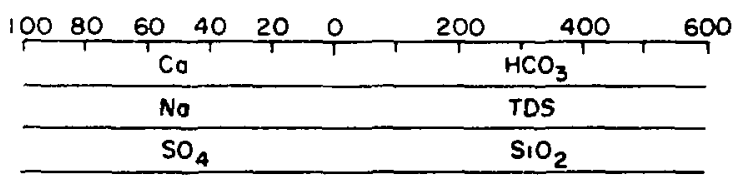

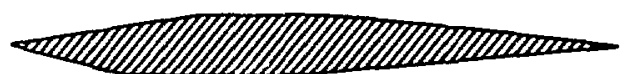

MORTANDAD
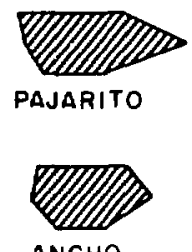

ANCHO

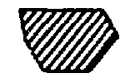

FRIJOLES

Fig. 5.

Graphic comparison of chemical characteristics of water from streams.
TABLE V

GROSS ALPHA, GHOSS BETA, AND TOTAL $U$ IN WATER FROM STREAMS (Analyses in $\mathrm{pCi} / \ell$ except as noted)

\begin{tabular}{|c|c|c|}
\hline Stream & $\begin{array}{l}\text { Gross } \\
\text { Alpha }\end{array}$ & $\begin{array}{l}\text { Gross } \\
\text { Beta }\end{array}$ \\
\hline Mortandad & $<0.5$ & 18 \\
\hline Pajarito & 2.5 & 4.3 \\
\hline Ancho & $<0.5$ & 2.2 \\
\hline Frijoles & $<0.5$ & 3.4 \\
\hline
\end{tabular}

\section{SUMMARY AND CONCLUSIONS}

Twenty-seven springs are located in the reach of White Rock Canyon from Otowi to the confluence of Frijoles Canyon. Chemical quality of water from the 
springs is separated into four groups. Three groups have similar aquifer related chemical quality. Group I springs discharge a calcium and bicarbonate type water from the Totavi Lentil. Group II springs discharge a sodium and bicarbonate type water from coarse-grained sediments of the Tesuque Formation. Croup III springs discharge a sodium and bicarbonate water from fine-grained sediments of the Tesuque Formation. Water from G:oup III springs contains slightly higher chemical concentrations than the water from Group II springs. Group IV consists of five springs, La Mesita, Ancha, 2A, 3B, and ('aniada, each having slighly different chemical characteristics because of localized conditions of the aquifer. In general. chemical constituents in water Irom the Group IV springs are higher than those tourd in Groups I. II, and III springs.

(hemical quality of water from individual springs has varied slightly in samples collected from 1964 through 1979. The variations are normal due to seasimal variations and are not considered signifi. cant.

Fuur streams enter : he Rio Grande in White Rock (anyon from Otowi to the confluence of Frijoles (anyon. The quality of water in Mortandad Canyon reflects the quality of treated sanitary effluent released from the plant at White Rock. The effluent has little or no effect on the quality of water in the Rio Grande because of the dilution factor. The quality of water in Pajarito Canyon reflects the base flow from Group I springs in the Totavi Lentil. The quality of water in Ancho Canyon reflects mainly the base flow from Group I springs in the Totavi Lentil, which is modified slightly by some discharge from the coarse-grained sediments of the Tesuque Formation befol ine stream reaches the Rio Grande. Base $110 \mathrm{w}$ in Frijoles Canyon is from springs about $13 \mathrm{~km}$ west of the Rio Grande. The wildfire in June 1977 in the drainage area of Frijoles Canyon had only slight eflect on the quality of water at the river.

The chemical quality of water from the springs and streams is good. The concentrations of $\mathrm{SO}_{4}, \mathrm{C} \ell$, $\mathrm{F} . \mathrm{NO}_{3}$, and TDS are below drinking water standards with the exception of $\mathrm{NO}_{3}$ in sanitary effluents found in Mortandad Canyon. It should be noted that no bacteria samples were collected and analyzed. Thus, the chemical quality may be good, but the water from the springs and streams may not be potable due to bacteria.

\section{REFERENCES}

1. W. D. Purtymun and S. Johansen, "General Geohydrology of the Pajarito Plateau," N. M. Geol. Society Guidebook, 25th Field Conf.. Ghost Ranch, Central Northern New Mexico (1974).

2. R. L. Bostun, "General Geology and Hydrology of North-Central Santa Fe County, New Mex. ico," New Mexico State Engineer open-file report (1968).

3. \%. Spiegel and B. Baldwin, "Geology and Water Resources of the Santa Fe Area, New Mexico," U.S. Geol. Survey Water-Supply Paper 1525 (1963).

4. W. D. Purtymun. "Geology and Hydrology of White Rock Canyon from Otuwi to the Confluence of Frijoles Canyon, Los Alamos and Santa Fe Counties, New Mexico," U.S. Geol. Survey open-file report (1966).

5. Environmental Surveillance Group H-8, "Environmental Surveillance at Los Alamos During 1977," Los Alamos Scientific Laboratory report LA-728.3-MS (1978).

6. Environmental Surveillance Group H-8, "Environmental Surveillance at Los Alamos During 1978," Los Alamos Scientific Laboratory report LA-7800-ENV (1979).

7. Environmental Surveillance Group H-s, "Environmental Surveillance at Los Alamos During 1979," Los Alamos Scientific Laboratory report LA-8200-ENV (1980).

8. V. C. Kelley, "Tectonics of the Rio Grande Depression of Central New Mexico," N. M. Geol. Society Guidebook, 3rd Field Conference, Rio Grande County (1952).

9. R. L. Griggs, "Geology and Water Resources of the Los Alamos Area, New Mexico," U.S. Geol. Survey Water-Supply Paper 1753 (1964). 
10. U.S. Environmental Protection Agency, "National Interim Primary Drinking Water Regulations," (EPA-570/9-76-003), EPA, Office of Water Supply (1976).

11. New Mexico Environmental Improvement Department, "Water Supply Regulations," New Mexico Environmental Improvement Department. Santa Fe, New Mexico (1977).
12. W. D. Purtymun and H. Adoms, "Geohydrology of Bandelier National Monument, New Mexico," Los Alamos Scientific Laboratory report LA8161-MS (1980)

13. Li. S. Geological Survey, "Water Resources Data for New Mexico for Water Year 1978," U.S. Geol. Survey Water-Data Report NM-78-1 (1979). 